\title{
DESALINASI AIR PAYAU DENGAN MEDIA ADSORBEN ZEOLIT DI DAERAH PESISIR PANTAI KECAMATAN SUNGAI KUNYIT KABUPATEN MEMPAWAH
}

\author{
Darmawansa1), Nelly Wahyuni, S.Si. M.Si2), Dian Rahayu Jati.,ST.,MT11) \\ 1) Program Studi Teknik Lingkungan Jurusan Teknik Sipil Fakultas Teknik Universitas Tanjungpura, Pontianak \\ 2) Program Studi Kimia Fakultas MatematikaIlmuPengetahuanAlam Universitas Tanjungpura, Pontianak \\ Email: darmawan_sa@yahoo.co.id
}

\begin{abstract}
ABSTRAK
Daerah pesisir sering dihadapkan pada masalah keterbatasan sumber daya air yang berkaitan dengan kelangkaan air tawar yang dapat dimanfaatkan sebagai air bersih. Oleh karena itu diperlukan upaya alternatif untuk merancang sebuah teknologi sederhana pengolah air payau. Penelitian ini bertujuan untuk mengetahui seberapa besar nilai optimum penurunan salinitas air payau dengan media adsorben zeolit berdasarkan debit aliran air dan ukuran partikel zeolit serta merancang teknologi pengolah air payau menjadi air tawar dengan media adsorben zeolit yang optimum. Sampel yang digunakan berasal dari sumur warga pesisir sungai Kunyit Kabupaten Mempawah. Variabel bebas dalam penelitian ini adalah debit aliran air yaitu 100, 120, 140, 160, 180 dan $200 \mathrm{ml} /$ menit dan ukuran partikel zeolit adalah 0,5; 1; 1,5 dan $2 \mathrm{~mm}$. Pengambilan sampel diambil di tiga titik sepanjang pesisir pantai sungai kunyit Kabupaten Mempawah. Jenis mineral zeolit ditentukan dengan difraktrometer sinar-X ,sedangkan pengujian penurunan salinitas menggunakan metode argentometri. Jenis mineral zeolit yang digunakan pada penelitian ini yaitu mordenit. Hasil pengujian menunjukkan bahwa nilai optimum penurunan salinitas air payau menggunakan media adsorben zeolit sebesar 27,31 \% dengan debit optimum $160 \mathrm{ml} /$ menit, ukuran partikel zeolit optimum sebesar 1,5 mm. Model rancangan desalinator didesain menggunakan debit sebesar $160 \mathrm{ml} / \mathrm{menit}$, ukuran zeolit sebesar 1,5 mm dengan diameter tabung 2 inchi dan tinggi $1 \mathrm{~m}$.
\end{abstract}

Kata Kunci : Zeolit, Adsorbsi, Penurunan Salinitas, Model Rancangan Desalinator

\begin{abstract}
Coastal areas are often faced with the problem of limited water resources related to the scarcity of fresh water that can be used as clean water. Therefore we need an alternative attempt to design a simple technological processing brackish water. This study aims to determine how large a decrease in the value of the optimum salinity brackish water with zeolite based adsorbent media flow rates and particle size of the zeolite as well as designing technology processing brackish water into fresh water with optimum zeolite adsorbent media. The samples were taken from wells coastal residents Turmeric riverMempawah District. The independent variable in this study is that flow rates of 100,120,140,160,180 and $200 \mathrm{ml} / \mathrm{min}$ and particle size of the zeolite is 0.5; 1; 1.5 and $2 \mathrm{~mm}$. Sampling was taken at three points along the river coast turmeric Mempawah regency. Type zeolite minerals difraktrometer determined with X-rays, while the decrease in salinity testing method argentometry. Type zeolite minerals used in this study, namely mordenite. The test results showed that the optimum value decrease salinity brackish water using zeolite adsorbent media was $27.31 \%$ with optimum flow $160 \mathrm{ml} / \mathrm{min}$, the optimum particle size of $1.5 \mathrm{~mm}$ zeolite. Desalinator design model is designed to use a debit of $160 \mathrm{ml} / \mathrm{min}$, the size of the zeolite at $1.5 \mathrm{~mm}$ with a tube diameter of 2 inches and a height of $1 \mathrm{~m}$.

Keywords: Zeolite, Adsorbsi, Decreased Salinity, Draft Model desalinator
\end{abstract}




\section{PENDAHULUAN}

Daerah pesisir sering dihadapkan pada masalah keterbatasan sumber daya air. Secara kuantitas, daerah pesisir umumnya memiliki air yang melimpah, tetapi sering kali sulit mendapatkan air untuk berbagai penggunaan, karena kualitasnya tidak memadai. Keterbatasan sumber daya air di daerah pesisir berkaitan dengan kelangkaan air tawar yang dapat dimanfaatkan sebagai air bersih.Pengaruh air laut terhadap tata air amat kuat di wilayah pesisir dan mempengaruhi kualitas air secara umum. Secara kimia, besarnya pengaruh air laut tercermin pada tingginya salinitas. Air yang memiliki salinitas terlalu tinggi dapat mendatangkan kerugian apabila dipergunakan untuk kegiatan- kegiatan tertentu, misalnya berbahaya untuk kesehatan bila digunakan sebagai air minum, menyebabkan kegagalan panen bagi pertanian, korosi bagi peralatan dan bangunan yang terbuat dari unsur logam. Air payau adalah campuran antara air tawar dan air laut (air asin). Jika kadar garam yang dikandung dalam satu liter air adalah antara 0,5 sampai 30 gram, maka air ini disebut air payau. Namun jika konsentasi garam melebihi 30 gram dalam satu liter air disebut air asin (Suprayogi, 2006).

Berfokus didaerah Sungai Kunyit Kabupaten Mempawah, masyarakat disana memanfaatkan air sumur untuk kebutuhan sehari- hari seperti mencuci, mandi dan lain-lain. Berdasarkan pengamatan yang dilakukan peneliti di lapangan, di daerah Sungai Kunyit belum ada PDAM sehingga masyarakat menggunakan air sumur. Air sumur yang mereka gunakan merupakan air payau sehingga diperlukan pengolahan terlebih dahulu.

Teknologi sederhana yang dapat mengolah air payau menjadi air tawar adalah dengan proses filtrasi dengan memanfaatkan adsorben. Berdasarkan penelitian dari pusat penelitian informatikaLIPI menyatakan bahwa air payau dan air laut dapat diolah menjadi air tawar dengan prinsip adsorbsi menggunakan zeolit. Hasil penelitian tersebut menunjukkan kapasitas penyerapan $\mathrm{Na}^{+}$ antara 0,07 sampai dengan 0,67 meq/100g (Adil Jamali dkk, 2013). Berdasarkan penelitian yang dilakukan oleh Gustian dan Totok (2005) menyatakan bahwa zeolit yang telah diaktivasi mampu menyerap kadar garam $\mathrm{Na}^{+}$sebesar $80 \%$. Selain menyerap ion $\mathrm{Na}^{+}$, zeolit yang telah diaktivasi juga mampu mengurangi bau amoniak dalam air dan menyerap logam. Berdasarkan pertimbangan tersebut, maka diperlukan upaya alternatif untuk merancang sebuah teknologi sederhana pengolah air payau dengan memanfaatkan zeolit sebagai adsorben. Dengan teknologi ini diharapkan dapat mengolah air payau menjadi air tawar sebagai bahan baku air bagi masyarakat didaerah Sungai Kunyit Kabupaten Mempawah.

\section{METODE PENELITIAN}

\section{A. Lokasi dan waktu}

Penelitian dan perancangan dilaksanakan laboratorium Teknik Lingkungan Universitas Tanjungpura sedangkan pengmbilan sampel air menggunakan air sumur yang ada di daerah pesisir pantai Sungai Kunyit Kabupaten Mempawah. Adapun titik sampling yang diambil yaitu :

Titik $1 \quad$ : berjarak \pm 91 meter dari garis pantai.

Titik $2 \quad$ : berjarak \pm 177 meter dari garis pantai.

Titik 3 : berjarak \pm 560 meter dari garis pantai.

\section{B. Jenis Sampel Air}

Jenis sampel yang digunakan pada penelitian ini yaitu sampel gabungan tempat. Sampel gabungan tempat (integrated sample) merupakan sampel gabungan yang diambil secara terpisah dari beberapa tempat, dengan volume yang sama. 


\section{Bahan}

Bahan-bahan yang digunakan dalam penelitian ini diantaranya 20 liter air payau, $1 \mathrm{~kg}$ zeolit yang ada dijual dipasaran, kertas saring, air suling, larutan natrium klorida $(\mathrm{NaCl}) 0.0141 \mathrm{~N}$, larutan baku perak nitrat $\left(\mathrm{AgNO}_{3}\right) 0.0141 \mathrm{~N}$, larutan indikator kalium kromat $\left(\mathrm{K}_{2} \mathrm{CrO}_{4}\right) 5 \% \mathrm{~b} / \mathrm{v}$.

\section{Peralatan}

Alat - alat yang digunakan dalam penelitian ini yaitu pipa PVC 2 inchi dan $1 / 2$ inchi, bak penampung, stopkran, tee, mour PVC, buret $50 \mathrm{ml}$, labu erlenmeyer $100 \mathrm{ml}$ dan $250 \mathrm{ml}$, labu ukur $100 \mathrm{ml}$ dan $1000 \mathrm{ml}$, gelas ukur $100 \mathrm{ml}$, pipet ukur $10 \mathrm{ml}$, gelas piala $1000 \mathrm{ml}$, spatula, corong gelas, timbangan analitik.

\section{E. Metode Pengumpulan Data}

Data Primer yang digunakan dalam penelitian ini yaitu data yang diukur langsung dari air payau, meliputi salinitas, Sedangkan sekundernya yaitu data yang berasal dari referensi atau datadata serta berdasarkan baku mutu pemerintah dan studi kepustakaan.

\section{F. Variabel Penelitian}

Adapun variabel terikat pada penelitian ini adalah salinitas, ketinggian media dan diameter tabung. Variabel bebas pada penelitian ini adalah debit aliran dan ukuran zeolit. Debit aliran yang divariasikan yaitu $100 \mathrm{ml} /$ menit, $120 \mathrm{ml} /$ menit, $140 \mathrm{ml} /$ menit, $160 \mathrm{ml} /$ menit, $180 \mathrm{ml} / \mathrm{menit}$, 200 $\mathrm{ml} /$ menit. Sedangkan untuk ukuran zeolit divariasikan dengan ukuran 0,5 mm,1 mm, 1,5 mm dan 2 $\mathrm{mm}$.

\section{G. Rangkaian Alat Pengolahan Air Payau}

Pada rangkaian alat disiapkan absorben dalam kolom PVC dengan diameter ukuran 2 inchi dan tingginya 0,5 $\mathrm{m}$. Volume bak penampung yang digunakan 100 liter.

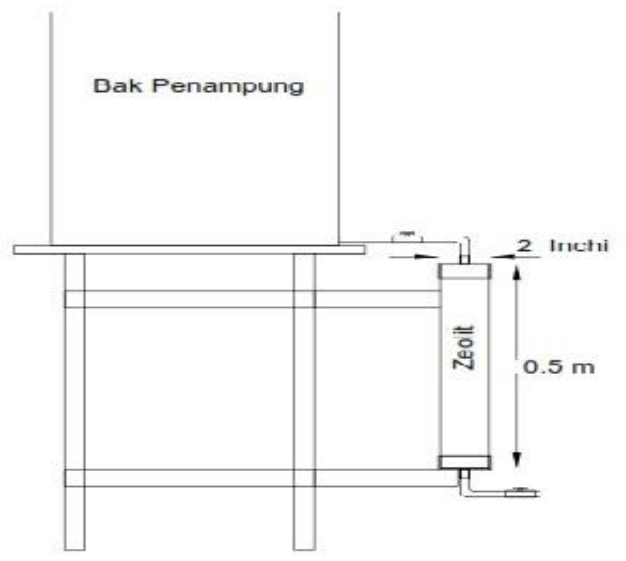

Gambar 1. Alat pengolahan air payau 


\section{H. Analisis Argentometri Pada Air Hasil Desalinasi (SNI, 2004)}

\section{- Persiapan Pengujian}

Pembakuan larutan baku perak nitrat $\left(\mathrm{AgNO}_{3}\right)$ dengan $\mathrm{NaCl} 0,0141 \mathrm{~N}$

Dimasukkan $25 \mathrm{ml}$ larutan $\mathrm{NaCl} 0.0141 \mathrm{~N}$ kedalam labu Erlenmeyer $100 \mathrm{ml}$. dibuatkan larutan blanko menggunakan $25 \mathrm{ml}$ air suling, kemudian ditambahkan $1 \mathrm{ml}$ larutan indicator $\mathrm{K}_{2} \mathrm{CrO}_{4} 5 \%$ b/v dan diaduk. Selanjutnya dititrasi dengan larutan AgNO3 sampai terjadi perubahan warna (warna merah kecoklatan) dan dicatat volume larutan $\mathrm{AgNO}_{3}$ yang digunkan untuk contoh uji (A-ml) dan blanko (B-ml). Pengujian dilakukan secara duplo. Apabila standar deviasi (SD) kadar klorida secara duplo lebih besar dari 5\%, maka dilakukan titrasi ke tiga. Kemudian dirata-ratakan volume $\mathrm{AgNO}_{3}$ yang digunakan dan dilakukan perhitungan normalitas larutan baku $\mathrm{N} \mathrm{AgNO}_{3}$ dengan rumus :

$$
\mathrm{NAgNO}_{3}=\frac{\mathrm{V}_{1} \mathrm{~N}_{1}}{\mathrm{~V}_{\mathrm{A}}-\mathrm{V}_{\mathrm{B}}}
$$

Dengan pengertian :

$\mathrm{N} \mathrm{AgNO}_{3}$ adalah normalitas larutan baku $\mathrm{AgNO}_{3}$ (mgrek/ml)

$V_{A} \quad$ adalah volume larutan baku $\mathrm{AgNO}_{3}$ untuk titrasi larutan $\mathrm{NaCl}(\mathrm{m} / \mathrm{l})$

$V_{B} \quad$ adalah volume larutan baku $\mathrm{AgNO}_{3}$ untuk titrasi blanko (m/l)

$N_{1} \quad$ adalah normalitas larutan $\mathrm{NaCl}$ yang digunakan (mgrek/ml)

$V_{1} \quad$ adalah volume larutan $\mathrm{NaCl}$ yang digunakan $(\mathrm{m} / \mathrm{l})$

\section{- Prosedur Penguji}

Diambil $100 \mathrm{ml}$ air sampel dan digunakan secara duplo, kemudian sampel air dimasukkan ke dalam labu Erlenmeyer $250 \mathrm{ml}$. dilakukan pembuatan larutan blanko. Pada sampel uji ditambahkan 1 ml larutan indicator $\mathrm{K}_{2} \mathrm{CrO}_{4} 5 \%$, kemudian dititrasi dengan larutan baku $\mathrm{AgNO}_{3}$ sampai titik akhir titrasi yang ditandai dengan terbentuknya endapan berwarna merah kecoklatan dari $\mathrm{Ag}_{2} \mathrm{CrO}_{4}$, lalu dicata volume $\mathrm{AgNO}_{3}$ yang digunakan. Dilakukan titrasi blanko terhadap $100 \mathrm{ml}$ air suling bebas klorida. Diulangi titrasi tersebut dua kali dan dirata-ratakan volume $\mathrm{AgNO}_{3}$ yang diperoleh. berikut:

Air hasil desalinasi dihitung kadar klorida dengan menggunakan persamaan rumus sebagai

$$
\begin{aligned}
& \text { Kadar } \mathrm{Cl} \frac{\overline{\mathrm{mg}}}{\mathrm{L}}=\frac{(\mathrm{A}-\mathrm{B}) \times \mathrm{N} \times 35,450}{\mathrm{v}} \\
& \text { dengan pengertian : } \\
& \text { A adalah volume larutan baku } \mathrm{AgNO}_{3} \text { untuk titrasi }(\mathrm{mL}) \\
& \text { B adalah volume larutan baku } \mathrm{AgNO}_{3} \text { untuk titrasi blanko }(\mathrm{mL}) \\
& \mathrm{N} \text { adalah normalitas larutan baku } \mathrm{AgNO}_{3}(\mathrm{mgrek} / \mathrm{mL}) \\
& \text { V adalah volume contoh uji }(\mathrm{mL}) \\
& \text { Perhitungan Kadar Garam : } \\
& \mathrm{mg} / \mathrm{L} \mathrm{NaCl}=\left(\mathrm{mg} / \mathrm{L} \mathrm{Cl}^{-}\right) \times 1,65
\end{aligned}
$$

\section{Analisis Data}

Dari analisa akan dapat diketahui berapa besar penurunannya.

a. Untuk efisiensi

Adapun rumus yang digunakan untuk menetukan efisiensi dapat dilihat pada persamaan 4 berikut.

$$
\begin{aligned}
& \text { Efisiensi }(\%)=\frac{S_{0}-S}{S_{0}} \times 100 \% \\
& \mathrm{~S}_{0}=\text { kadar parameter sebelum pengolahan } \\
& \mathrm{S}=\text { kadar parameter sesudah pengolahan }
\end{aligned}
$$




\section{HASILDANPEMBAHASAN}

\section{A. Analisa Sampel Air}

Analisa sampel air payau dilakukan untuk mengetahui kandungan kadar garam pada air tersebut. Air payau yang dianalisa ini merupakan air payau yang berasal dari sumur yang ada di rumah penduduk pesisir pantai Sungai Kunyit. Sampel air payau ini dianalisa untuk mengetahui kandungan kadar garam awal sebelum air ini diolah. Sampel air payau diambil di tiga sumur yang berbeda. Tujuan pengambilan di tiga sumur ini untuk mengetahui masing- masing kadar garamnya di setiap sumur sehingga dapat mewakili pengolahan yang akan dibuat. Setelah sampel air diambil di setiap sumur kemudian dilakukan analisa kandungan salinitasnya. Pada saat pengolahannya, sampel air di tiga sumur digabungkan menjadi satu tempat dengan volume sampel setiap sumur 20 liter. Kemudian diukur salinitasnya. Penggabungan tersebut dimaksudkan untuk menentukan rerata konsentrasi kadar garam dalam air sampel di sepanjang pesisir Sungai Kunyit. Hasil analisa sampel air payau di tiga sumur pesisir pantai Sungai Kunyit dapat dilihat pada tabel 1 :

Tabel 1. Analisa Sampel Air Payau

\begin{tabular}{c|c|c}
\hline Air Sampel & $\mathrm{Cl}^{-}(\mathrm{g} \mathrm{Cl}-$ liter $)$ & Salinitas $(\mathrm{mg} / \mathrm{liter})$ \\
\hline Sumur 1 & 0,68 & 1,13 \\
Sumur 2 & 1,11 & 1,84 \\
Sumur 3 & 0,97 & 1,61 \\
Gabungan & 0,92 & 1,53 \\
\hline
\end{tabular}

Sumber : Hasil analisis

Berdasarkan hasil analisis yang diperoleh di ketiga sumur tersebut memiliki kadar garam yang cukup tinggi melewati standar salinitas air tawar yaitu 1,53 mg/liter atau 0,92 $\mathrm{g} \mathrm{Cl}-/$ liter . Secara kuantitatif, mutu air payau mengandung klorida antara $0,5 \mathrm{~g} \mathrm{Cl} /$ liter sampai dengan $10 \mathrm{~g} \mathrm{Cl} / \mathrm{liter}$ masih diklasifikasikan sebagai air payau. Merujuk pada baku mutu air bersih (PP No.82, 2001), kandungan klorida dalam air bersih adalah maksimal 0,6 g Cl-/liter (Sarwoko, 2010).

\section{B. Analisa Zeolit yang Digunakan}

Sampel zeolit yang digunakan yaitu zeolit yang ada dipasaran. Zeolit ini dianalisis untuk mengetahui jenis mineral penyusun zeolit yang digunakan pada penelitian ini. Analisis zeolit menggunakan metode $X$-Ray Diffraction $(X R D)$. Berdasarkan hasil analisa terdapat empat tipe zeolit yang mungkin digunakan yaitu Cristobalite $b$, Heulandite, Mordenite, Orthoclase. Penentuan jenis zeolit ini ditentukan berdasarkan interval relatif (\%) dan 20. Dari gambar 3.1 menunjukkan nilai tipe zeolit yang digunakan yaitu tipe dengan nilai $2 \theta$ sebesar 22,43 dan interval relatif sebesar 100 $\%$. Berikut Gambar 2 yang menunjukkan jenis mineral dari zeolit yang digunakan sebagai adsorben dalam penelitian ini.

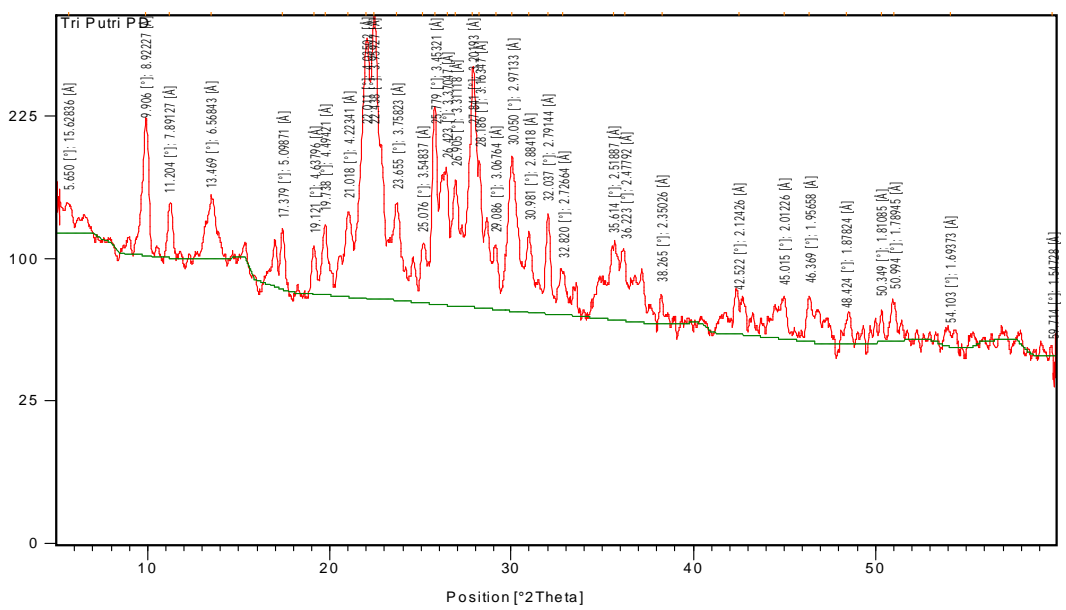

Gambar2.DifragtogramZeolit yang Digunakan 
Menurut hasil-hasil penelitian terdahulu ,zeolit alam yang telah diaktivasi dapat digunakan sebagai adsorben untuk menyerap beberapa jenis ion. Zeolit memiliki struktur pori dengan ukuran tertentu dan luas permukaan yang besar sehingga dapat berfungsi sebagai penyerap dengan selektivitas dan kemampuan penyerapan yang cukup tinggi. Sruktur zeolit memiliki pori dengan ukuran tertentu menyebabkan molekul-molekul dengan ukuran kecil mampu terserap dalam struktur zeolit. Struktur zeolit yang mempunyai pori biasanya diisi oleh molekul air yang dapat dipertukarkan dengan kation-kation yang sesuai, seperti $\mathrm{Ca}^{2+}, \mathrm{Na}^{+}, \mathrm{K}^{+}, \mathrm{Mg}^{2+}$ (Guisnet, dalam Indah 2001).

\section{Pengaruh Debit Terhadap Salinitas}

Dari percobaan yang dilakukan, zeolit digunakan sebagai adsorben yang dibuat sebagai filter. Ketinggian zeolit yang digunakan yaitu $50 \mathrm{~cm}$ dengan diameter tabung filter 5,08 cm. Ukuran zeolit yang digunakan yaitu 1,5 mm. Variasi debit memiliki kemampuan berbeda - beda untuk menurunkan salinitas.

Gambar 3 menunjukkan hasil yang didapat dari percobaan yang dilakukan berdasarkan penurunan salinitas terhadap variasi debit .

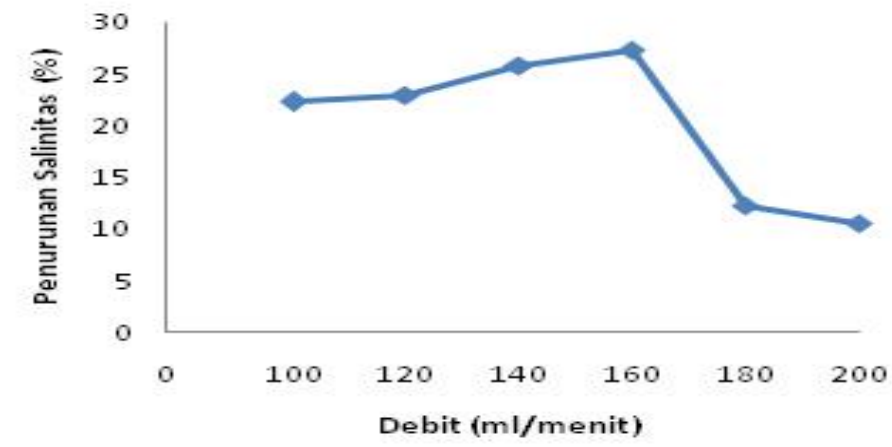

Gambar 3. Grafik Hubungan Antara Debit Aliran Terhadap Salinitas

Gambar 3 menunjukkan presentasi penurunan salinitas semakin besar seiring dengan meningkatnya debit. Pada debit dari $100 \mathrm{ml} /$ menit penurunan salinitas sebesar $22 \%$ meningkat sampai pada debit $160 \mathrm{ml} /$ menit sebesar 27,31\%. Namun, pada debit 180 sampai $200 \mathrm{ml} / \mathrm{menit}$ penurunan salinitas semakin kecil sebesar 12,28 \% dan 10,53\%.

Berdasarkan penelitian yang dilakukan oleh Ratih Suci Apriani dkk (2010), bahwa semakin lama waktu kontak yang terjadi maka semakin kecil debit aliran air sehingga penyisihan $\mathrm{Na}^{+}$dan $\mathrm{Cl}^{-}$ semakin besar.

Peningkatan penurunan salinitas pada debit $100 \mathrm{ml} /$ menit sampai $160 \mathrm{ml} / \mathrm{menit}$ terjadi karena tekanan yang dihasilkan semakin besar yang menyebabkan air dapat menembus jarak antar permukaan partikel. Pada pengujian yang telah dilakukan terdapat beberapa partikel zeolit yang tidak terkontak dengan air sehingga tidak terjadi penyerapan pada permukaan zeolit tersebut yang dikarenakan debit aliran air kecil.

Pada debit antara $160 \mathrm{ml} /$ menit dengan $200 \mathrm{ml} /$ menit menyebabkan semakin kecilnya penurunan salinitas. Debit aliran ini dipengaruhi waktu kontak dimana semakin besar debit aliran masuk maka waktu kontak semakin pendek sehingga proses penyerapan semakin baik. Hal ini disebabkan oleh waktu tinggal atau kontak adsorben dengan adsorbat hanya sebentar (KirkOthmer, dalam Ratih, 2010). Dapat dilihat pada Gambar 3 hasil yang didapat menunjukkan bahwa semakin cepat waktu kontak zeolit dengan air baku maka semakin besar penurunan salinitas. Pada debit $180 \mathrm{ml} /$ menit dengan waktu kontak yang semakin cepat menunjukkan semakin kecilnya penurunan salinitas. Menurut Reynold (1982), Semakin kecil debit yang digunakan mengakibatkan proses adsorbsi semakin baik, sebaliknya semakin besar debit yang digunakan maka proses adsorbsi akan berkurang. Ini dipengaruhi oleh waktu kontak antara air yang diolah dengan 
adsorbannya. Waktu kontak merupakan suatu hal yang sangat menentukan dalam proses adsorpsi. Waktu kontak yang lebih lama memungkinkan proses difusi dan penempelan molekul adsorbat berlangsung lebih baik. Ini terjadi karena kemampuan penyerapan adsorben di tiap debit berbedabeda.

\section{Pengaruh Ukuran Partikel Terhadap Salinitas}

Hasil analisa penurunan salinitas terhadap ukuran media ditampilkan pada tabel 2

Tabel 2. Analisa Penurunan Salinitas Terhadap Ukuran Media Zeolit

\begin{tabular}{c|c|c}
\hline $\begin{array}{c}\text { Ukuran } \\
(\mathrm{mm})\end{array}$ & Berat(gram) & $\begin{array}{c}\% \\
\text { Penurunan }\end{array}$ \\
\hline 2 & 1.524 & 10,25 \\
1,5 & 1.557 & 27,31 \\
1 & 1.664 & 16,87 \\
0,5 & 1.667 & 11,98 \\
\hline
\end{tabular}

Sumber : Hasil analisis

Pada Tabel 2 menunjukkan variasi ukuran adsorben menggunakan aliran debit $160 \mathrm{ml} / \mathrm{menit}$. Faktor yang mempengaruhi adsorbsi dalam menurunkan salinitas adalah ukuran zeolit. Ukuran zeolit menentukan luas permukaan adsorben.Semakin luas permukaan adsorben, semakin banyak adsorbat yang diserap, sehingga proses adsorpsi dapat semakin efektif. Semakin kecil ukuran diameter adsorben maka semakin luas permukaannya. Kapasitas adsorpsi total dari suatu adsorbat tergantung pada luas permukaan total adsorbennya (Sawitri, 2008).

Proses adsorpsi tergantung pada banyaknya tumbukan yang terjadi antara partikel-partikel adsorbat dan adsorben. Tumbukan efektif antara partikel itu akan meningkat dengan meningkatkanya luas permukaan. Jadi, semakin luas permukaan adsorben maka adsorpsi akan semakin besar. Semakin kecil ukuran partikel maka waktu kontak akan berlangsung lebih lama. Waktu untuk mencapai keadaan setimbang pada proses serapan logam oleh adsorben berkisar antara beberapa menit hingga beberapa jam (Bernasconi, 1995).

Berdasarkan Tabel2 dapat dibuat grafik hubungan antara kadar salinitas dengan variasi ukuran. Hasil pengolahan tersebut dapat dilihat Gambar 4 sebagai berikut.

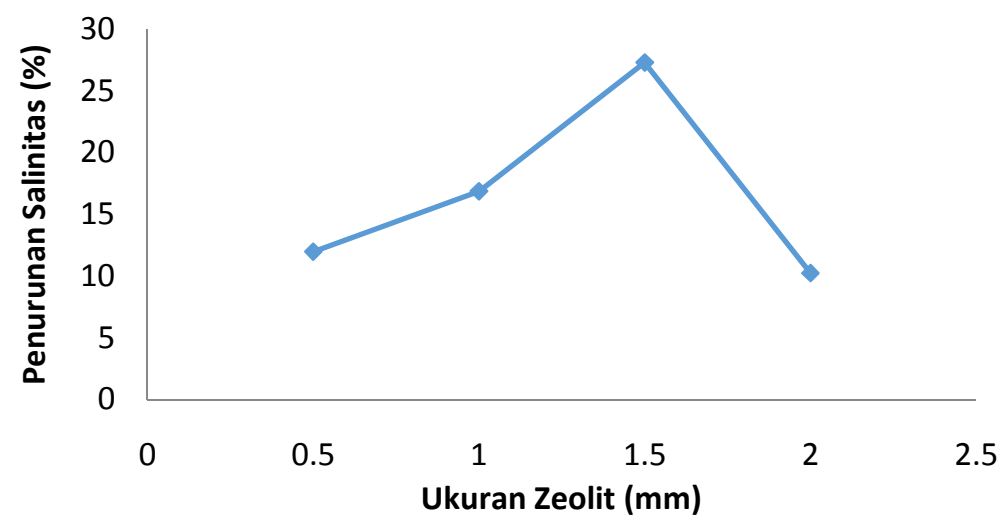

Gambar 4. Grafik Hubungan Antara Ukuran Zeolit Terhadap Salinitas

Gambar 4menunjukkan bahwa penurunan salinitas dengan menggunakan variasi ukuran zeolit mengalami penurunan pada ukuran zeolit 1,5 mm dengan efisiensi sebesar $27,31 \%$.

Selain itu faktor yang mempengaruhi penurunan salinitas dari variasi ukuran adalah berat zeolit. Dari tabel 3.3 juga menunjukkan berat zeolit dalam tabung dari variasi ukuran. Berat zeolit pada ukuran optimum 1,5 adalah 1557 gram. Pada penelitian ini variabel tetap yang digunakan 
adalah ketinggian dan diameter tabung filter. Ini berpengaruh pada banyaknya zeolit dalam tabung filter. Semakin kecil ukuran zeolit dalam tabung maka semakin banyak zeolit yang ada. Menurut Banny Syahputra (2009), perbedaan berat bahan adsorben memiliki kemampuan berbeda- beda dalam menurunkan salinitas $(\mathrm{NaCl}$ dan $\mathrm{Cl}$ ). Penurunan kadar salinitas sejalan dengan penambahan berat adsorben. Berat adsorben dikarenakan kecilnya ukuran partikel.

Dari grafik menunjukkan semakin besar ukuran partikel yaitu dari 0,5 sampai 1,5 semakin besar pula penurunan salinitas. Ini terjadi dikarenakan faktor jumlah zeolit pada tabung filter. Pada ukuran tabung filter yang sama dengan berbedanya ukuran tiap partikel menyebabkan semakin banyak pula zeolit yang ada dalam tabung. Pada ukuran zeolit yang kecil akan terjadi pemadatan antara partikel zeolit yang satu dengan yang lainnya sehingga antar permukaan zeolit bertemu dan merapat dan mengkibatkan tidak adanya kontak air pada permukaan zeolit tersebut. Sedangkan pada ukuran $2 \mathrm{~mm}$ penurunan salinitas semakin kecil yaitu 11,98\%. Penurunan ini terjadi karena luas permukaan semakin kecil. Semakin besar ukuran partikel zeolit dalam tabung filter mengakibatkan semakin kecil luas permukaan partikel zeolit sehingga jumlah pori-pori pada partikel zeolit berkurang.

\section{E. Model Rancangan}

Dari penelitian yang dilakukan didapatlah nilai optimum debit dan ukuran zeolit untuk mengolah air payau di pesisir pantai sungai kunyit kabupaten mempawah. Jadi, untuk merancang model pengolahan air payau di daerah pesisir pantai Sungai Kunyit Kabupaten Mempawah dapat dihitung menggunakan mempertimbangkan kapasitas pemakaian air bersih setiap rumah tangga.

Diketahui :

Debit penelitian $\left(\mathrm{Q}_{1}\right)$

Waktu aliran dalam filter

Tinggi tabung filter $\left(\mathrm{T}_{1}\right)$

Diameter tabung filter

Kebutuhan air 1 orang

Yang dilayani

1 kepala keluarga

: $160 \mathrm{ml} /$ menit $=2,7 \times 10-5 \mathrm{~m}^{3} /$ det

: 25 detik

: $0,5 \mathrm{~m}$

: 2 inchi $=0,05 \mathrm{~m}$

: 100 liter $/ 24$ jam

: 1 Kepala Keluarga

: 5 orang

Ditanya : dimensi alat skala rumah tangga?

Jawab :

Kecepatan aliran air dalam tabung filter $\left(\mathrm{V}_{1}\right)=\frac{0,5 \mathrm{~m}}{25 \mathrm{det}}=0,02 \mathrm{~m} / \mathrm{det}$

Volume pemakaian air $=1 \mathrm{KK} \times 5$ orang $\times 100$ liter $=500$ liter $=0,5 \mathrm{~m}^{3}$

Debit pemakaian rumah tangga $\mathrm{Q}_{2}=\frac{0,5 \mathrm{~m}^{3}}{24 \mathrm{jam}}=5,7 \times 10^{-5} \mathrm{~m}^{3} / \mathrm{det}$

Pada perencanaan untuk skala rmah tangga diameter yang digunakan 2 inchi sehingga

$\mathrm{A}_{1}=\mathrm{A}_{2}=\frac{1}{4} \pi d^{2}=\frac{1}{4} 3,14(0,05)^{2}=0,0019 \mathrm{~m}^{2}$

Ketinggian filter $\left(\mathrm{T}_{2}\right)$

$$
\begin{gathered}
\frac{v}{v}=\frac{A_{1} T_{1}}{A_{2} T_{2}} \\
\frac{2,7 \times 10^{-5 \mathrm{~m}^{3} / \text { det }}}{5,7 \times 10^{-5} \mathrm{~m}^{3} / \text { det }}=\frac{0,0019 \mathrm{~m}^{2} \times 0,5 \mathrm{~m}}{0,0019 \mathrm{~m}^{2} T_{2}} \\
2,1=0,5 T_{2} \\
T_{2}=1,05 \mathrm{~m}
\end{gathered}
$$

Jadi untuk mengolah air payau skala rumah tangga dengan kapasitas 500 liter/hari diperlukan dimensi filter dengan diameter 2 inchi dan ketinggian 1,05 m. 


\section{KESIMPULAN DAN SARAN}

\section{A. Kesimpulan}

- Nilai optimum penurunan salinitas air payau menggunakan media adsorben zeolit sebesar 27,31 \% dengan debit optimum $160 \mathrm{ml} /$ menit, ukuran partikel zeolit sebesar 1,5 mm.

- Model rancangan desalinasi didesain menggunakan debit sebesar $160 \mathrm{ml} / \mathrm{menit}$, ukuran zeolit sebesar 1,5 mm dengan diameter tabung 2 inchi dan tinggi 1 meter.

\section{B. Saran}

- Sebaiknya dilakukan penambahan variasi debit dan ukuran partikel zeolit.

- Sebaiknya dilakukan analisa GSA (Gas Sorption Analizer) untuk mengetahui ukuran pori zeolit yang digunakan.

\section{Ucapan Terimakasih}

Dengan selesainya penelitian ini saya mengucapkan terima kasih yang sebesar-besarnya kepada Tuhan Yang Maha Esa, kedua orang tua, kedua dosen pembimbing yaitu Ibu Nelly Wahyuni, S.Si, M.Si dan Ibu Dian Rahayu Jati St, M.Si serta kepada teman-teman Teknik Lingkungan 2009 dan semua orang yang telah berperan dalam membantu penelitian yang tidak dapat di ucapkan satu persatu. Harapan saya penelitian ini dapat bermanfaat bagi semua dan dapat dipergunakan sebagaimana mestinya.

\section{Referensi}

Adil Jamali, Kalzani Jafri, M. Amin dan Widi Astuti. 2003. Pengolahan Air Payau Menggunakan Mineral Zeolit. Pusat Penelitian Informatika-LIPI. Bandung. Pemaparan Hasil Litbang. Juli 2003 : A208 - A218

Bambang Poerwadi, dkk. 1998. Pemanfaatan Zeolit Alam Indonesia Sebagai Adsorben Limbah Cair dan Media Fluiditas dalam Kolom Fluidisasi. Unversitas Brawijaya. Malang

Benny Syahputra. 2009. Perancangan Trickling Filter dengan Media Batu Apung Sebagai Upaya Penurunan Salinitas Air Payau. Universitas Islam Sultan Agung. Semarang. Jurnal Studi Lingkungan Vol.1, No.1 Mei 2009 : 47-56

Bernasconi, G.H. et al. 1995. Teknologi Kimia. PT. Pradnya Paramita. Jakarta

Gustian I dan Totok ES.2005.Studi Penurunan Salinitas Air Dengan Menggunakan Zeolit Alam Yang Berasal Dari Bengkulu.Jurnal Gradien Vol.1 No.1 Januari 2005 : 38-42

Guisnet, M. 2002. "Coke" Molecules Trapped in The Micropores of Zeolites as Active Species in Hydrocarbon Transformations, J. Mol. Catal., 182-183, 367-382.

Hardyanti, N dan Nurmeta, DF.2006. Studi Evaluasi Instalasi Pengolahan Air Bersih Untuk Kebutuhan Domestik Dan Nondomestik (Studi Kasus Perusahaan Tekddtil Bawen Kabupaten Semarang).Jurnal Prespitasi Vol.1 No.1 September 2006. ISSN 1907-187X

Indah Nurhayati. 2001. Filtrasi dengan Media Zeolit Teraktivasi Untuk Menurunkan Kesadahan, Jurusan Teknik Lingkungan FTSP Universitas PGRI Adi Buada. Surabaya. Jurnal Wahana Volume 57, No 2, Desember 2001

Kirk, R.E. dan Othmer, D.F. 1981.Encyclopedia of Chemical Technology. 3thed., Vol 4, John Wiley and Sons, Inc. New York. pp. 561-570

Ratih Suci Apriani, Putu Wesen. 2010.Penurunan Salinitas Air Payau Dengan Menggunakan Resin.Prodi Teknik Lingkungan, Fakultas Teknik Sipil dan Perencanaan.Universitas Pembangunan Nasional. Surabaya. Jurnal Ilmiah Teknik Lingkungan, 2 (1). pp. 64-77

Reynolds, Tom D. 1982. Unit Oprations and Process in Enviromental Engineering.California: Texas A\&M University, Brooks/Cole Engineering Division 
Sawitri, D. E., dan Sutrisno, T. 2006. Adsorpsi Krom (VI) dari Limbah Cair Industri Pelapisan Logam dengan Arang Eceng Gondok (Eichornia crossipes). Jurusan Teknik Kimia, Fakultas Teknik, Universitas Diponegoro. Semarang. Jurnal Sains Pomits Vol. 1, No. 1,2012 1-6

Suprayogi I, Nadjndji A, Dijatnol dan Muhammad I. 2006.Fenomena Intrusi Air Laut Di Estrusi Akibat Pengaruh Tinggi Pasang Air Laut Dengan Debit Hulu Sungai Menggunakan Pendekatan Model Fisik.ParifikasiVol.7 No.2. Hlm 133 - 138 